\title{
Capparaceae in the flora of Egypt
}

\author{
Zeinab A.R. El Karemy \\ Botany Department, Faculty of Science, \\ Assiut University, Assiut, Egypt
}

El Karemy Z. A. R. 2001. Capparaceae in the flora of Egypt. Taeckholmia 21(2):257-267.

\begin{abstract}
A systematic revision of the native species of the family Capparaceae (Cleome excluded) was carried out. The presence of Boscia angustifolia in Egypt is uncertain, while Capparis spinosa is represented in Egypt by 3 varieties viz. : spinosa, inermis \& deserti.

Diagnostic characters of the taxa are given and a key for the separation of species and varieties, synonyms and notes on distribution are provided. SEM features of the leaf epidermis were proved to be of taxonomic significance.
\end{abstract}

Key words: Boscia, Cadaba, Capparaceae, Capparis, Dipterygium, Egypt; Maerua.

\section{Introduction}

The Capparaceae is a medium-sized family, containing 40-50 genera with about 700 species. Few of its members are of horticultural or economic importance. The family inhabits the warmer parts of the world, mainly in the tropics and subtropics of both hemispheres and in the Mediterranean. It is well represented by about 15 genera in Africa where it forms a conspicuous element of the flora of dry regions.

It is generally agreed that the Capparaceae is allied to the Cruciferae and that both are evolved from a common ancestor. Heywood (1978), referred to some relationships that this family has with the Papaveraceae and Resedaceae.

The present work deals with the native taxa belonging to the genera : Capparis, Cadaba, Boscia, Maerua and Dipterygium. Special attention is paid to the earlier applied characters as well as other macro- and micromorphological characters which were not the subject of earlier investigations and which may prove their of systematic value.

SEM features of the leaf epidermis, viz. of the cell patterns, anticlinal cell boundaries and the periclinal cell walls, show a wide range of variation and provide useful diagnostic characters. Various works have shown that these microcharacters can be used at generic, specific and even at infrasecific level (Ball \& Heywood, 1962; El-Karemy \& Hosni, 1993; Mc Clure, 1957 and Syed et al. 1990).

The present account is based on the collections of Cairo University Herbarium (CAI) and Assiut University Herbarium as well as field observations.

With the exception of Capparis spinosa var. inermis, which is confined to the Mediterranean coastal land of Egypt and C. spinosa var. deserti which is confined to the northwestern corner of the country (Sollum, Matruh and Siwa area), the remaining investigated taxa are distributed mainly within the Sahelian scrub in Gebel Elba district. 


\section{Characters of systematic value}

\section{Habit}

Among the investigated species, only Dipterygium glaucum is a perennial herb, not exceeding $80 \mathrm{~cm}$ high. Boscia senegalensis and Maerua crassifolia are trees, attaining 6m tall, while the remaining species are shrubs, or climbing on other trees.

\section{Leaf characters}

Leaf characters proved to be of great importance for the distinction of the investigated taxa. The leaves are generally present, except in Capparis decidua and Dipterygium glaucum which are almost leafless. Leaves are simple, being occasionally digitally compound in Dipterygium glaucum. Furthermore, the leaves are more or less ovate in outline, or linear-oblong to linear in Capparis decidua and Dipterygium glaucum. The leaves of the majority of the investigated taxa are almost glabrous or possess simple hairs. In Cadaba glandulosa the leaves are densely covered with long-stalked glandular hairs. They are densely covered with short-stalked, white, peltate hairs (farina) in Cadaba farinosa hence the specific name of the species. In Cadaba rotundifolia the leaves are densely to sparsely covered with swollen- based hairs (Fig. 2b).

Stipular characters are very useful in the differentiation between the infraspecific taxa of Capparis. In Capparis spinosa var. spinosa (including var. canescens), the stipules are often spinose; in var. inermis the stipules are setaceous and inconspicuous, whereas var. deserti is characterised by patent yellow stipular spines.

On the other hand, leaf venation is of special interest in Boscia senegalensis, where the leaves are distinctly reticulate, with 5-6 lateral nerves raised on both surfaces and prominently looped.

\section{Floral Characters}

The calyx in most of the revised taxa is characterised by subequal sepals. In Capparis decidue and C. cartilaginea, the posterior sepal is the largest and helmet-shaped.

Petals are absent in Cadaba rotundifolia, C. glandulosa, Boscia senegalensis and Maerua crassifolia (Fig. 1). In Capparis decidua the petals are red, and range in colour between white and yellow in the rest of the studied taxa. Species of Capparis and Maerua are characterised by flowers with numerous stamens, whereas the stamens number is limited in Cadaba (4-5), in Dipterygium (6) and in Boscia (4-9); (Fig. 1).

The species of Cadaba are characterised by a long ligulate appendage (nectary) attached to the gynophore. Cadaba farinosa is characterised by tubular nectary which is shortly toothed at the tip and not exceeding $5 \mathrm{~mm}$ long, it is tubular and petaloid above, reaching $2 \mathrm{~cm}$ long in Cadaba rotundifolia and Cadaba glandulosa (Fig.1).

\section{Fruit characters}

The present investigation proved that the characters of the fully developed fruit, applied by earlier investigators, are still among the most reliable diagnostic characters. 


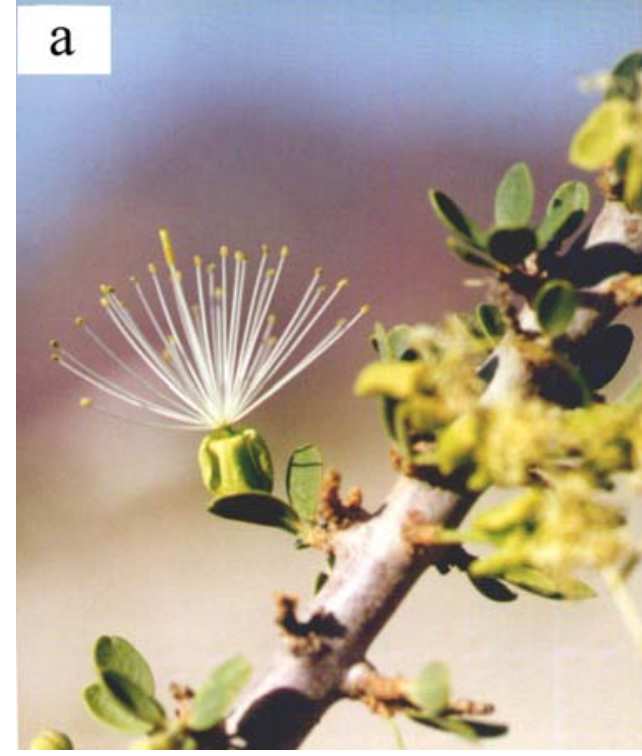

(x 1)

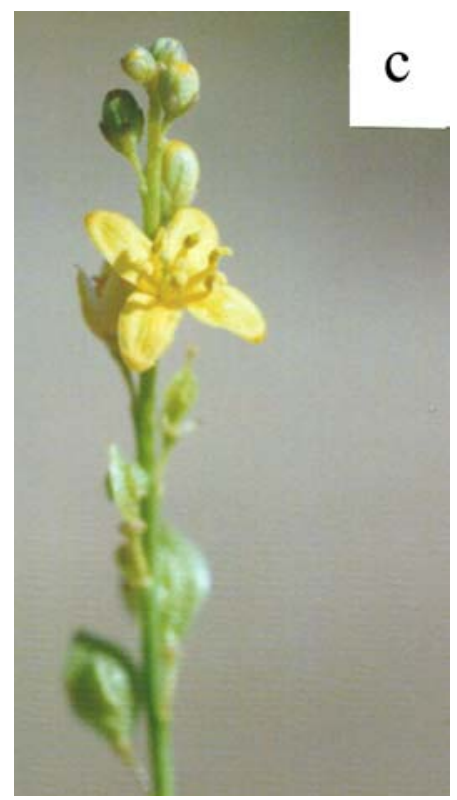

(x 3)

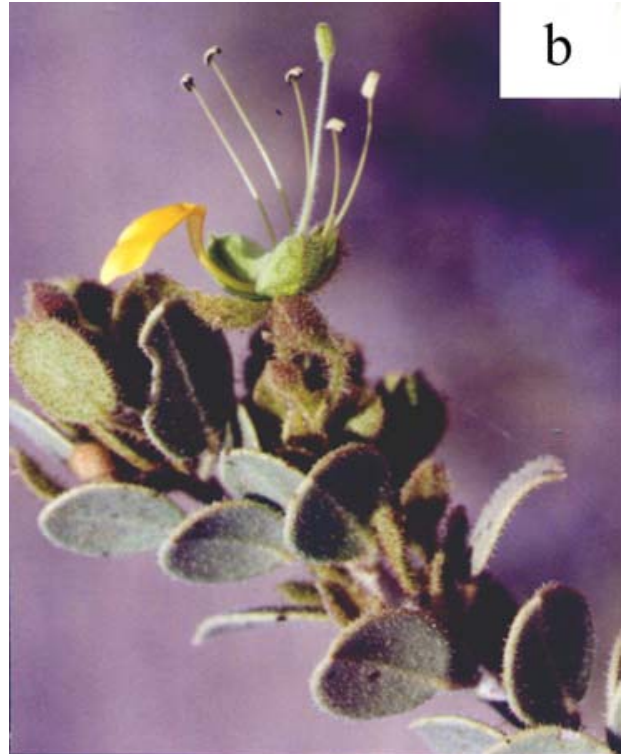

(x 1.5)

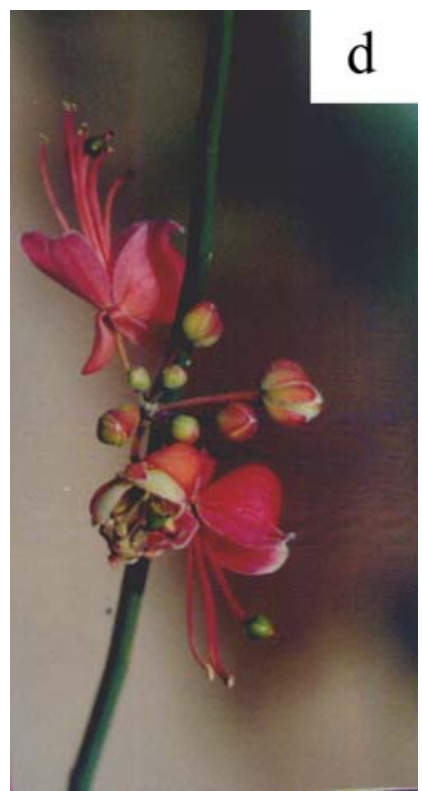

(x 2)

Figure 1. Flowers and fruits of representative species

a. Maerua crassifolia (petals 0, stamens $\propto$ ); b. Cadaba glaindulosa (petals 0, nectarial appendage petaloid, stamens 5); c. Dipterygium glaucum (petals 0, stamens 5); d. Capparis decidua (sepals unequal with the posterior larger and helmet-shaped). 


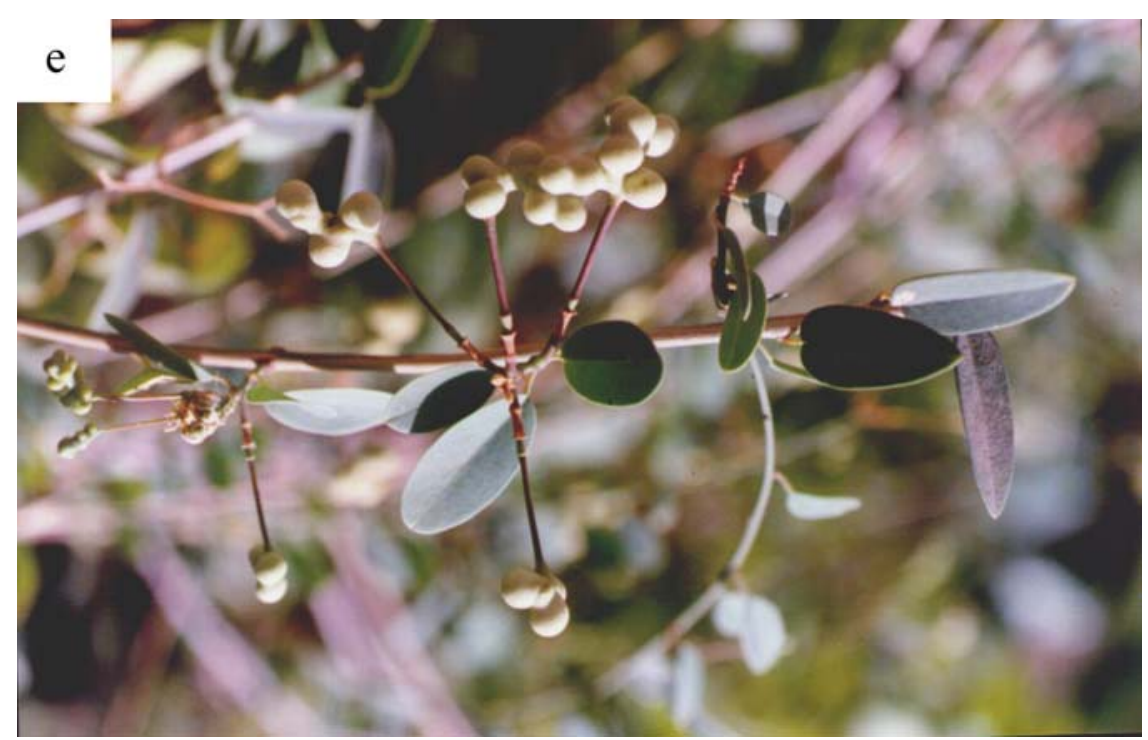

(x 4.0)

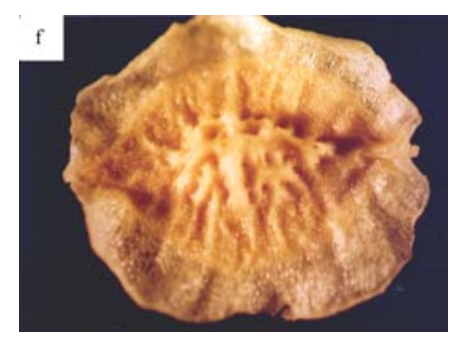

(x 10)

Figure 1, continued. Flowers and fruits of representative species:

e, Maerua oblongifolia (unilateraly torulose); f, Dipterygium glaucum (narrowly winged, muricate).

\section{4.a . Shape and size}

Five shape categories are recognized: pyriform (Capparis spinosa and C. cartilaginea), globose (Capparis decidua and Boscia senegalensis), cylindrical (Cadaba species), torulose (Maerua species) and elliptic in Dipterygium glaucua (Fig.1f).

The smallest fruits are those of Dipterygium glaucum and Capparis decidua, where the fruit measures between 3.5 and $15 \mathrm{~mm}$ long. In Boscia senegalensis the fruit is larger, ranging between 1-2.5 cm long. In Cadaba species the fruit measures 1-5x0.2-0.8 $\mathrm{cm}$, while those of Maerua species it measure 1-2.5×2-4 cm. The largest fruits are those of Capparis spinosa and Capparis cartilaginea being 2.5-5.5x4-9 cm.

\section{4.b . Indumentum}

Most species are characterized by more or less minutely tomentose or even glabrous fruits. In Cadaba glandulosa the fruit is covered with long-stalked glands, while those of C. farinosa are farinose. 


\section{5 . SEM features of leaf epidermis (Figure 2)}

Most of the investigated species are characterized by almost glabrous leaves, only in studied species Cadaba, the leaves are glaudular-hairy. The hair structure was found very useful in the distinction of the Cadaba species. In Cadaba glandulosa, the leaves are densely covered with long stalked glandular hairs. In Cadaba farinosa, the leaves are densely covered with white peltate hairs which constitute the white indumentum leaf covering (farina) characteristic to this species. In Cadaba rotundifolia, the leaves are densely to sparsely covered with swollen- based glandular hairs.

Generally the investigated epidermal cells were found to be more or less isodiametric or elongated in one direction, while the anticlinal boundaries are slightly raised, sinuate and smooth. On the other hand, the periclinal cell walls were found to be variable within the examined species. In Dipterygium glaucum they are flat, and in Boscia senegalensis the periclinal cell walls are distinctly reticulate. In Capparis species they are reticulate with the exception of Capparis decidua where the periclinal cell walls are microstriate. Moreover, Capparis decidua, C. cartilaginea and Boscia senegalensis are characterized by sunken stomata namely.

\section{Systematic treatment}

\section{Capparis $L$.}

The genus Capparis comprises about 250 species, mainly in tropical regions of both hemisphers, nearly half of which are American. Zohary (1960), recognised six species of Capparis occurring in the Mediterranean and Near Eastern countries.

According to Täckholm (1974), six species, including one variety were reported from Egypt viz: Capparis decidua (Forssk.) Edgew., C. cartilaginea DC., C. aegyptia Lam., C. leucophylla DC. (including var. microphylla (Ledeb.) Täckh.), C. deserti (Zoh.) Täckh. and C. orientalis Duh.

The presnt revision revealed the presence of three species of which Capparis spinosa L. is polymorphic and includes three varieties:

1.1. Capparis decidua (Forssk.) Edgew., Proc. Linn. Soc. Bot. 6 : 184 (1862).

Syn.: Sodada decidua Forssk., Fl. Aegypt.- Arab. 81 (1775).

Type : Arabia, Yemen, Forsskal ( C ).

Distribution : Uncommon shrub in the desert plains and wadi beds. Known from N. and Tropical Africa, Arabia, eastwards to India.

Representative specimes : Red Sea hills, wadi Atalla, 24.3.1965, Osborn \& Helmy s.n. (CAI); Mersa Alam, Feb. 1977, El-Gazzar (CAI); Gebel Elba, 23.1.1929, G. Täckholm s.n. (CAI). 

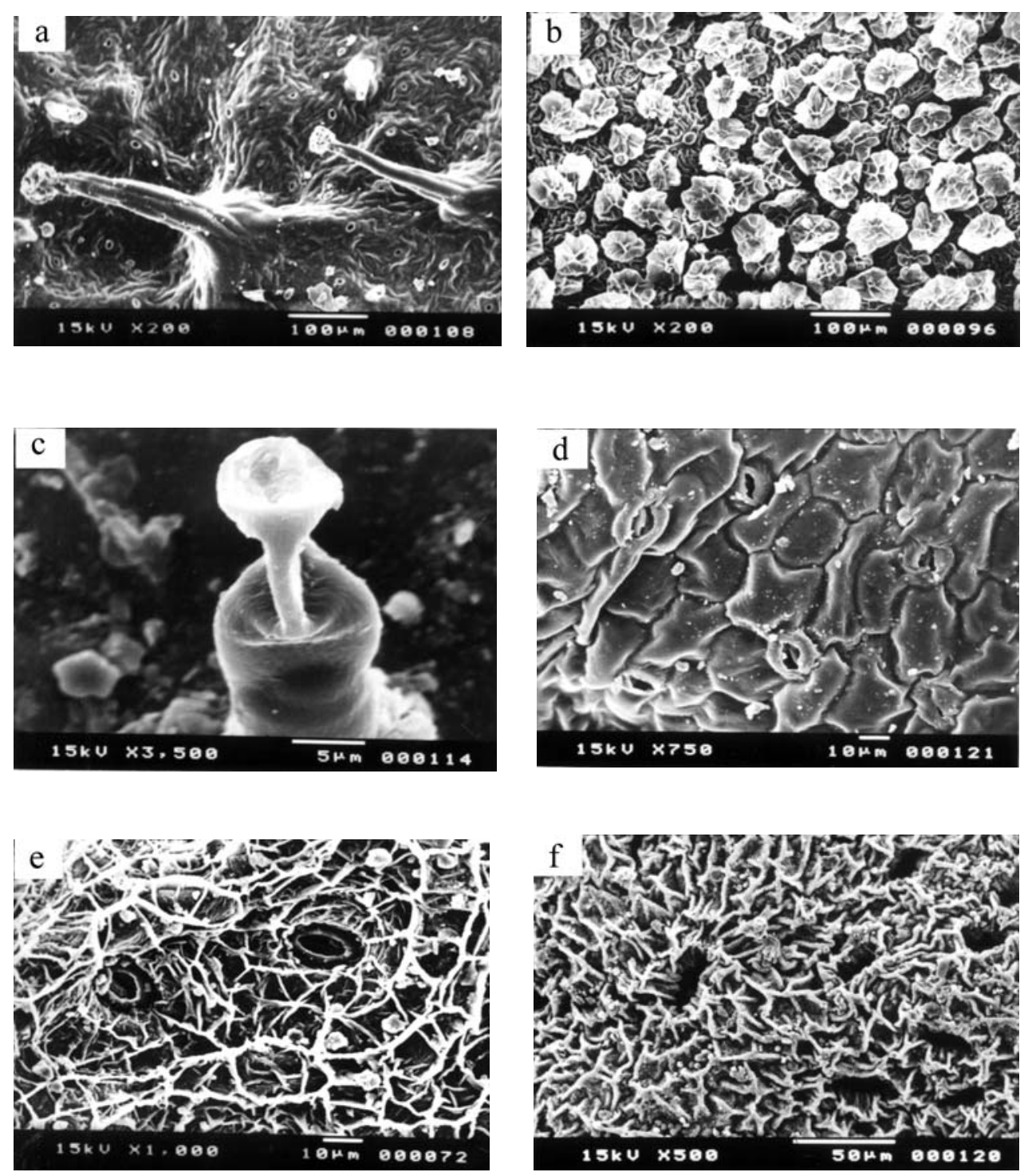

Figure 2. SEM features of leaf epidermis among the investigated species of Capparaceae. a. Cadaba glaindulosa, indumentum of long stalked glandular hairs; b. Cadaba farinosa, white indumentum of peltate hairs; c. Cadaba rotundifolia, indumentum of swollen based glandular hairs; d. Dipterygium glaucum, epidermal cell flat with slightly raised stomata; e. Capparis spinosa var. spinosa, epidermal cell walls reticulate with sunken stomata; f. Boscia sensegalensis, epidermal cell walls reticulate with sunken stomata. 
1.2. Capparis cartilaginea Decne., Ann. Sci. Nat. Bot., ser. 2, 3: 273 (1835).

Syn.:Capparis sinaica Veill. In Duh., Traite. Arbr. Arbust., ed. 2,1:144 (180); Capparis galeata Fresen., Mus. Senkenb. 2 : 111 (1837).

Type : Egypt, Sinai, Bové 148 (P).

Distribution: Common on rocks of Wadi beds. Known from S.W. and E. Africa, Palestine, Iraq, Arabia, S. Iran and Pakistan.

Representative specimens : S. Galala, Wadi Askhar, 14.5.1945, Shabetai 5824 (CAI); Gebel Al-Shayeb, 11.2.1960, Täckholm et al s.n (CAI) ; Sinai, mountain region, April 1956, El Hadidi s.n (CAI); Gebel Elba, Wadi Mawaw, 28.1.1962, Täckholm et al. s.n. (CAI).

1.3. Capparis spinosa L., Sp. Pl., ed. 1.503 (1753) .

Represented in Egypt by three varieties:

\subsection{1. var. spinosa}

syn.: Capparis aegyptia Lam., Encycl. 1:605 (1785); Capparis spinosa L. var. aegyptia (Lam.) Boiss., Fl. Orient. 1:420 (1867); Capparis spinosa var. canescens Coss., Notes pl. crit. 1:28 (1848) ; Capparis leucophylla DC., Prodr. 1:246 (1824).

Type : Specimen labelled as Capparis aculeata in herb. Hort. Cliff. (BM).

Representative specimens : Sinai, St. Catherine Monastry, 10.5.1956, El Hadidi s.n. (CAI); Wadi Hof, 14.4.1930, Oliver s.n. (CAI) ; Red Sea coast, 10.5.1956, Täckholm 24 (CAI); $130 \mathrm{~km} \mathrm{~S} \mathrm{Mersa} \mathrm{Matruh,} \mathrm{on} \mathrm{the} \mathrm{way} \mathrm{to} \mathrm{Siwa,} \mathrm{27.10.1963,} \mathrm{Boulos} \mathrm{s.n.} \mathrm{(CAI).}$

1.3.2. var. inermis Turra, Fl. Ital. Prodr. 65 (1780).

syn.: Capparis orientalis Duh., Traite Arbr., ed. 2,1:142 (1801); Capparis spinosa L. subsp. orientalis (Duh.) Jafri in Ali \& Jafri, Fl. Libya 12:3 (1977).

Type: “Les rochers de l'isle de Crete et des iles de l'Archipel, particulierement celle d'Antiparos; en Syrie et dans la Palestine”.

Representative specimens : Sollum, 24.5.1963, Täckholm et al. s.n. (CAI); Wadi Agiba, 5.3.1976, Täckholm et al. s.n. (CAI); Mariut, 2.5.1955, El Hadidi s.n. (CAI).

1.3.3. var. deserti Zohary, Bull. Res. Council Israel D, 8:54 (1960).

syn.: Capparis deserti (Zohary) Tackh. Boulos, Publ. Cairo Univ.Herb. 5:14 (1974).

Type: not designated.

Representative specimens : Road between Mersa Matruh and Siwa Oasis, near Bir El Basm, 90 km from Mersa Matruh, 10.8.1953, Boulos s.n. (CAI); 145 km from Mersa Matruh, 10.8.1953, Abdel-Fadeel 47 (CAI). 
Distribution of the species: Wadis and cliffs in the Eastern and Western deserts. Known from the Mediterranean region, W. and Central Asia to India.

\section{Cadaba Forssk.}

The genus Cadaba includes 30 species, chiefly in the tropics of the Old World, especially Africa. It is characterised by the long ligulate appendage of the gynophore, the nectary.

Cadaba is called after the Yemen plant name as "Qadab" which is the local name for Cadaba rotundifolia (Wood, 1997). Three species occur in Egypt.

\subsection{Cadaba rotundifolia Forssk., Fl. Aegypt. - Arab. 68 (1775).}

Type : Yemen, Forsskal (C,BM).

Distribution: Confined to the Acacia bushland of the coastal plains and escarpment foothills of the southeastern parts of Egypt. Known from Sudan, Kenya, Ethiopia, Djibuti, Somalia, Saudi Arabia and Yemen.

Representative specimens : Gebel Elba; Wadi Kansisrob, 4.2.1933, Drar s.n; 24.10.1956, Boulos (CAI); Wadi Serimtai, 23.1.1962, Täckholm et al. 354 (CAI) - Khor Wadi Siamtit, Täckholm et al. 354 (CAI).

\subsection{Cadaba glandulosa Forssk., Fl. Aegypt. - Arab. 68 (1775).}

Type : Yemen, Forsskal (C ).

Distribution: Confined to the Acacia bushland on rocky slopes of Gebel Elba distinct. Known from Sudan, Uganda, Kenya, Tanzania, Mali, Saudi Arabia and Yemen.

Representative specimens : Gebel Elba; Gebel Alafoot, 7.2.1962. Täckholm et al. 1680 (CAI).

\subsection{Cadaba farinosa Forssk., Fl. Aegypt. - Arab. 68 (1775).}

Type : Yemen, Forsskal (C).

Distribution : In Egypt, confined to the Acacia bushland, on rocky and sandy slopes of the southeastern desert. Widespread in tropical Africa, Arabia, Pakistan and India.

Representative specimens: Mersa Halaib, 21.1.1929, G. Täckholm s.n. (CAI); Gebel Elba: Wadi Aideib, 20.1.1962, Täckholm et al. 129 (CAI); Khor Wadi Siamtit, 23.1.1962, Täckholm et al. 358 (CAI); Wadi Oalak, 27.1.1962, Täckholm et al. 668 (CAI) ; Wadi Mera Kwan, 10.2.1962, Täckholm et al. 2047 (CAI).

\section{Boscia Lam.}

Comprises 37 species, mainly in tropical and southern Africa. Represented in Egypt by Boscia senegalensis. 
3.1. Boscia senegalensis Poir. In Lam., Tab. Encycl. 2:517 (1819).

Type : not designated.

Distribution: Rare on the stony ground of the southwestern parts of Egypt. Known also from Sudan, Chad, Nigeria and Senegal. It is doubtfully recorded in Arabia.

Representative specimens: Mersa Alam, Red Sea coast, Feb. 1977, El-Gazzar 52 (CAI).

Note: No specimens of Boscia angustifolia A. Rich. reported by El Hadidi \& Fayed (1994/95) and Boulos (1999) was seen by the author. It is known from Tropical Africa, southwestern Saudi Arabia and northwestern Yemen (Nyberg, 1996; Wood, 1997). The occurrence of this species in Egypt is uncertain.

\section{Maerua Forssk.}

It comprises 50 species, mainly tropical and southern Africa to India.

This genus was named by Forsskal based on Arabic name, 'Miru', which is used for Maerua crassifolia in Yemen (Wood, 1997).

Two species occur in Egypt.

4.1. Maerua crassifolia Forssk., Fl. Aegypt. - Arab.: CXIII, 104 (1775).

Type : Yemen, Forsskal (C).

Distribution: Uncommon on sandy or gravelly plains and stony hills of the Eastern Desert and Sinai. Also known from north and tropical Africa, Palestine, Arabia, Iran and Pakistan.

Representative specimens: Wadi Monbatah, Cairo - Suez road, 13.1.1961, Täckholm et al. s.n. (CAI); Wadi El Qattar, near Hurghada, 5.6.1960, Täckholm et al. s.n. (CAI); Sinai, on the cliffs, near Abu Zeneima, 10.5.56, Täckholm et al. s.n. (CAI); Gebel Um Gurdi, 11.2.1961, Täckholm et al. s.n. (CAI).

4.2. Maerua oblongifolia (Forssk.) A. Rich., Tent. Fl. Abyss. 1:32 (1847).

Syn.: Capparis oblongifolia Forssk. Fl. Aegypt.- Arab. 99 (1775); Capparis mithridatica Forssk. Fl. Aegypt.- Arab. 99 (1775).

Type : Yemen, Forsskal (C,BM).

Distribution: Frequent in the protection of Acacia and other bushes in the southeaster parts of Egypt. Also known from Tropical Africa, southwestern Saudi Arabia, Yemen and Oman.

Representative specimens : Gebel Elba: Wadi Aideib, 20.1.1961, Täckholm et al. s.n. (CAI); North - West and West slopes of Gebel Asotriba, 28.1.1962, Täckholm et al. s.n. (CAI). 


\section{Dipterygium Decne.}

A monotypic genus placed by some authors in the Cruciferae (Täckholm, 1974). Hedge et al. (1980), discussed the history of its family assigment and pointed out that phytochemical data strongly reinforce its inclusion in the Capparaceae.

5.1. Dipterygium glaucum Decne., Ann. Sci. Nat. Bot., ser. 2,4:67 (1835).

Type : Saudi Arabia, Jeddah, Bové(P).

Distribution: Common in the sandy plains, gravelly and stony areas of the Egyptian deserts. Widely distributed in Tropical East Africa, Saudi Arabia, Yemen, Oman, Iran and Pakistan.

Representative specimens: Wadi Abu Nad, Hurghada district, 6.9.1960, Täckholm et al. s.n. (CAI). Wadi Yoider, 20.2.1967, Osborn \& Helmy s.n. (CAI); Gorge across Gebel Shallal, 24.1.1962, Täckholm s.n. (CAI).

\section{Key to the revised taxa}

1.a. Herbs; leaf epidermal periclinal cell walls flat Dipterygium glaucum

b. Shrubs or trees; leaf epidermal periclinal cell walls more or less reticulate or microstriate

2.a. Stipular thorns present ................................................................ 3

b. Stipular thorns absent ........................................................ 7

3.a. Plant soon leafless; leaves when present linear-oblong to linear; Petals red

b. Plant leafy; leaves mostly broadly ovate; petals white or cream 4

4.a. Sepals distinctly very unequal, with the posterior the largest and helmet- shaped

b. Sepals subequal 5

5.a. Stipular thorns setaceous, inconspicuous ....... Capparis spinosa var. inermis

b. Stipular thorns spinose 6

6.a. Fruit 25-50 mm long; petiole up to $10 \mathrm{~mm}$ long ................................................ Capparis spinosa var. spinosa

b. Fruit 10-20 mm long ; petiole not exceeding 5 mm long

7.a. Nectary appendage present ; leaves glandular - hairy

b. Nectary appendage absent; leaves not glandular-hairy

8.a. Leaves densely covered with short-stalked peltate hairs (farina); Stamens attached near the middle of the gynophore.

b. Leaves densely to sparsely covered with long - stalked, non-peltate hairs; stamens attached towards the base of the gynophore

9.a. Fruit glandular 9

b. Fruit non-glandular Cadaba glandulosa

0.a. Fruit globose or ovoid; leaf nerves raised Cadaba rotundifolia

b. Fruits cylindrical or torulose; leaf nerves not raised 
11.a. Leaves mostly more than $2.5 \mathrm{~cm}$ long, with 5-6 pairs of lateral nerves

b. Leaves not exceeding $1.2 \mathrm{~cm}$ long with reticulate venation

Boscia angustifolia

12.a. Climbing, puberulent shrubs Maerua oblongifolia

b. Non-climbing, glabrous shrubs or trees Maerua crassifolia

\section{Acknowledgements}

The author is greatly indepted to the staff of Cairo University Herbarium (CAI) for facilities provided. Thanks are also due to Prof. Dr. M.N. El Hadidi for useful comments.

\section{References}

Ball, P.W. \& H.V. Heywood. 1962. The taxonomic separation of cytological races of Kohlrauschia prolifera (L.) Kunth sensu lato, Watsonia,5: 113-116.

Boulos, L. 1999. Flora of Egypt vol. 1 (Azollaceae - Oxalidaceae), Al Hadara Publishing, Cairo.

El-Hadidi, M.N. \& Fayed, A.A. 1994/95. Materials for Excursion Flora of Egypt (EFE), Taeckholmia 15:38-39.

El-karemy, Z.A.R. \& Hosni, H.A. 1993. Systematic studies on the Egyptian species of the family Primulaceae, Feddes Repertorium, 104 (5/6) : 327-334.

Hedge, I.C., Kjaer, A.\& O.Malver. 1980. Dipterygium - Cruciferae or Capparaceae?, Notes from the Royal Botanic Garden Edinburgh 38 (2) : 247-250.

Heywood, V.H. 1978. Capparaceae, In: Heywood, V.H. (ed.), Flowering Plants of the World, Oxford Uni. Press, Oxford-London-Melbourne.

Mc.Clure, D.S. 1957. Seed characters of selected plant families, Iowa state College Sci. J. 31 : 649-682.

Nyberg, J.A. 1996. In: Miller, A.G. \& Cope, T.A. (eds.), Flora of the Arabian Peninsula and Socotra vol. 1., Edinburgh \& Kew.

Syed, Z.H., Marin, P., Silic, C., Qaiser, M.\& B. Petcovic. 1990. A micromorphological study of some representative genera in the tribe Saturejeae (Lamiaceae), Bot. $J$. Linn. Soc., 103 : 59-80.

Täckholm, V. 1974. Student's Flora of Egypt, Cairo.

Wood, J.R.I. 1997. A Handbook of the Yemen flora, Royal Botanic Gardens, Kew.

Zohary, M. 1960. The species of Capparis in the Mediterranean and the Near Eastern Counteries, Bull. Res. Counc. Of Israel, 8D: 49-64. 